\title{
Mapping the interactions between rivers and sand dunes: Implications for fluvial and aeolian geomorphology
}

Baoli, Liu*, Tom, J, Coulthard

Department of Geography, Environment and Earth Sciences, University of Hull, Cottingham Road, Hull, HU6 7RX, United Kingdom

Keywords: Fluvial-aeolian interaction; Dunes; River; Net transport direction; River direction; Geomorphology

\section{ABSTRACT}

The interaction between fluvial and aeolian processes can significantly change Earth surface morphology. When rivers and sand dunes meet, the interaction of sediment transport between the two systems can lead to change in either or both systems. However, these two systems are usually studied independently, which leaves many questions unresolved in terms of how they interact. This paper carries out a global inventory, using satellite imagery to identify 230 sites where there are significant fluvial-aeolian interactions. At each location key attributes such as wind/river direction, net sand transport direction, fluvial-aeolian meeting angle, dune type and river channel pattern were identified and relationships between each

\footnotetext{
* Corresponding author contact:

Tel: +44(0)1482 465039, Fax: +44(0)1482 466340, Email: Baoli.liu@2009.hull.ac.uk
} 
factor were analyzed. From these data, six different types of interaction were classified that reflect a shift in dominance between the fluvial and aeolian systems. Results from this classification confirm that only certain types of interaction were significant: the meeting angle and dune type, the meeting angle and interaction type and finally the channel pattern and interaction type. However, the findings also indicate the difficulties of classifying dynamic geomorphic systems from snapshot satellite images.

\section{Introduction}

Fluvial and aeolian action are important agents in modifying landscapes and shaping the surface of the Earth, over a range local to regional scales. In humid/sub-humid areas moving water is often the dominant process shaping the land surface (Charlton, 2008), while in areas where water resources are more limited wind can become the dominant process. Bullard and Livingstone (2002) and Field et al. (2009) summarise how changes in moisture can affect the balance between aeolian and fluvial processes suggesting the highest levels of fluvial-aeolian interaction occur where neither fluvial nor aeolian processes dominate .

Significant interactions between fluvial and aeolian processes have previously been noted in many places across the world (Goudie, 2013; Warren, 2013), for example, the great dunes of Pyla on the French coast (Tastet and Pontee, 1998), the Athabasca sand dunes along the William River in Canada (Smith and Smith, 1984), sand dunes in Yarlung Zangbo River valley 
in China (Li et al., 1999) and the sand dunes in Victoria valley in Antarctica (Bourke et al., 2009). Sedimentological research has also identified fluvial and aeolian interaction in the interbedded fluvio-aeolian sediments found in stratigraphic records (Mazzullo and Ehrlich, 1983; Langford and Chan, 1989; Veiga et al., 2002; Song et al., 2006; Williams, 2009). Reviewing the literature, fluvial and aeolian systems are largely studied separately, yet, Earth surface processes rarely operate independently of each other and, as described above, there are many locations where fluvial and aeolian processes operate together - and thus interact with each other. Furthermore, previous studies that have looked at the interactions between fluvial and aeolian processes tend to examine these from the perspective of either fluvial or aeolian research, with only a few examples where there is a balance or mixture of approaches.

From a fluvial perspective, researchers have observed how flow can affect the development of aeolian features. By the action of fluvial erosion, sand dunes bordering channels can be changed in both size and location. Alternatively, dune sand can slump into rivers as a result of over-steepening of dune flanks from river erosion and the sand is then transported and redeposited by river which, in turn, determines the location of new dunes sourced by this sediment (Langford, 1989; Han et al., 2007; Maroulis et al., 2007). These type of dunes are named source-bordering dunes as they closely border the downwind side of their sediment supply from sand bed streams. In addition, some river systems can intercept the sediment transport from dune fields to the extent that they block dune movement. For example, the Colorado River was found to be not only the boundary of Algodones dunefield but also at the end of the transport path of sand from the Mojave Desert (Sweet et al., 1988; Muhs et al., 2003). In Africa, the dunefields in Northern Sudan are terminated by the Nile River (Bullard and McTainsh, 2003), the Namib Sand Sea is terminated by the ephemeral Kuiseb River 
(Thomas et al., 1997), the Skeleton Erg ends at the Hoarusib River (Krapf et al., 2003) and the perennial Orange River marks the downwind margin of the southwest Kalahari dunefield (Ward, 1987; Thomas et al., 1997; Bullard and McTainsh, 2003; Krapf et al., 2003).

Contrastingly, aeolian process can heavily influence fluvial process. Sand dunes can deflect and confine overbank flows, dam and divert river courses and thus determine the position of many contemporary waterholes and channels (Langford, 1989; Loope et al., 1995; Maroulis et al., 2007). Jones and Blakey (1997) described how an ephemeral stream flowing along the edge of an erg in South Central Utah, USA was diverted several times by aeolian sands obstructing the river until it was forced to take a different route to the sea, leaving relic dry channels. In central Australia, previous floodplains of the Todd River are now new fields of dunes - though it is difficult to determine whether the climate change, large floods or possibly aeolian damming are responsible (Hollands et al., 2006). Additionally, some river systems can dramatically change pattern and behaviour when they encounter aeolian processes. For example, the lower William River in Canada undergoes a rapid adjustment from a relatively narrow and deep single-channel stream to a braided pattern when it encounters a large dune field (Smith and Smith, 1984). By studying the change of lithological and sedimentological characteristics in the Vecht valley from the Middle Pleniglacial to the Holocene, Huisink (2000) found a correspondence between historical changes in channel pattern and aeolian activity where low energy meandering rivers were associated with periods of low aeolian activity and high energy braided systems were associated with periods of high aeolian activity. It is unclear, however, whether these changes in channel style were caused by an influx of sediment resulting from aeolian activity or whether the climate change led to change in vegetation and thus bank stability. Furthermore, fluvial systems can supply sediment to, and be the primary 
sediment sources for, many sand seas and dunefields. For example in Israel, Roskin et al. (2011) found the sand supply and storage in Sinai was initiated by the Late Pleistocene exposure of the Nile Delta sands. Studies carried out in the Mojave Desert appear to prove that the sand in the Mojave Desert have been transported from the Mojave River Wash source (Ramsey et al., 1999). The Colorado River is shown to be the source of sand for at least three of the major dune fields of the Sonoran desert of western Arizona and northern Mexico (Muhs et al., 2003; Draut, 2012). In China, sedimentological and mineralogical analyses were carried out in two major sand areas on the Ordos Plateau and it was found that the dune sands were derived from local fluvial and lacustrine sediments (Peterov II, 1959; Zhu et al., 1980; Wu, 1987; Liu et al., 2005).

In some locations the balance between fluvial and aeolian action has changed over relatively short time-scales, which may correspond to seasonal changes (for example ephemeral rivers). This presents the scenario where during dry seasons, the sand may travel over a dried-up river channel that crosses its transport pathway. The river may then form an obstacle to aeolian transport when river levels rise (Muhs et al., 2000). For example, Xu et al. (2006) studied 56 basins of the Yellow River in China and observed that in the areas with seasonally alternating wind-water action, during winter and spring, the aeolian sands driven by strong winds move slowly across river channels covering dry river beds and filling small gullies. In the following summer, the aeolian sand stored on the river bed was removed by flood events. At the Sachs River in Canada, the fluvial deposits of the ephemeral streams and the channel are subject to aeolian modification during the arid summer months to the extent that interbedded fluvialaeolian sediments accumulate (Good and Bryant, 1985). 
As shown above, the interactions between fluvial and aeolian processes are clearly important for the development of many landscapes, yet there is relatively little research investigating these interplays. Langford (1989) documented six types of modern fluvial-aeolian interaction after observing the Medano Creek intermixed with the aeolian landforms in the Great Sand Dunes in America, including: (1) aeolian landforms dammed streams; (2) interdune areas were flooded, particularly alongside channels and behind aeolian dams; (3) dunes bordering flooded channels and interdunes were eroded; (4) fluvial sediment was deposited in interdune areas; (5) interdunes were flooded by groundwater derived from the fluvial system; and (6) fluvial sediment was eroded by the wind and blown into the aeolian system. However, these six types were only described in temperate climates and at a local scale. Therefore, there is a clear need to examine, describe and classify the interaction between fluvial and aeolian processes at a large (global) scale.

This paper aims to provide a global classification, establish what interaction types exist and how common they are. This is carried out using a global inventory of fluvial-aeolian interactions based on different data sources (Landsat images, published literature, station records, etc.). In the following sections, the different types of interaction are categorized, and at each site additional information is collected to determine what may control the interactions and how this may change the geomorphology.

\section{Methods}

This study used a global visual search of fluvial-aeolian interactions using remotely sensed imagery hosted on Google Earth (GE). Using such remotely sensed images, however, presents difficulties as these images can only identify surface features and landforms - in effect the 
symptoms of aeolian and fluvial action. For this reason the study focussed on the interaction between sand dunes and rivers as both features are readily identifiable. Sand sheets were not recorded as it is difficult to accurately differentiate them from bare or scrub ground at the resolution of the imagery used here (e.g. Fig. 1A, B). The survey also excluded vegetated dunes as vegetation adds a level of uncertainty to the behaviour of the dunes that is difficult to interpret from satellite imagery Fig. 1C, D). To augment the visual search examples from published studies were also used where available.
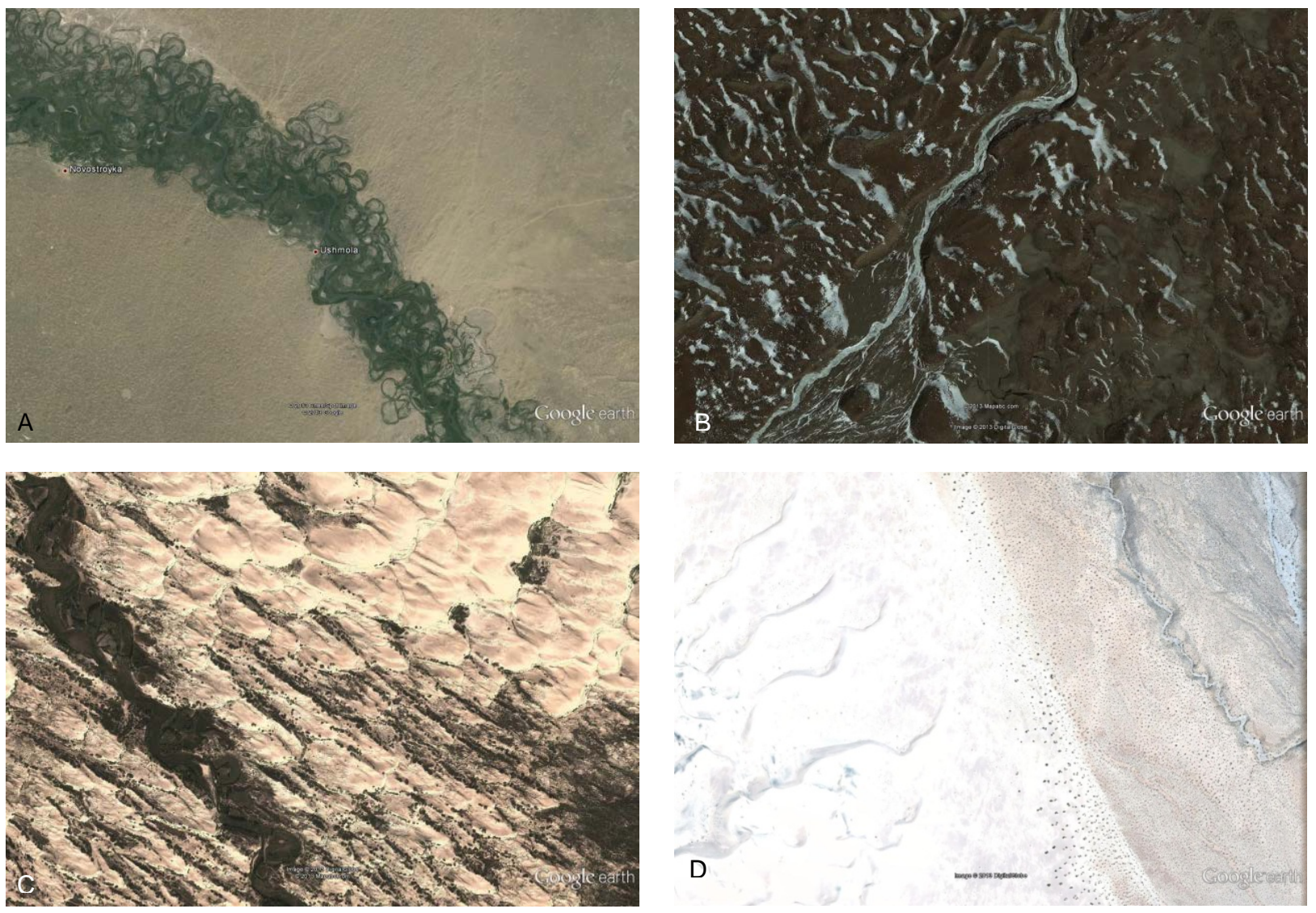


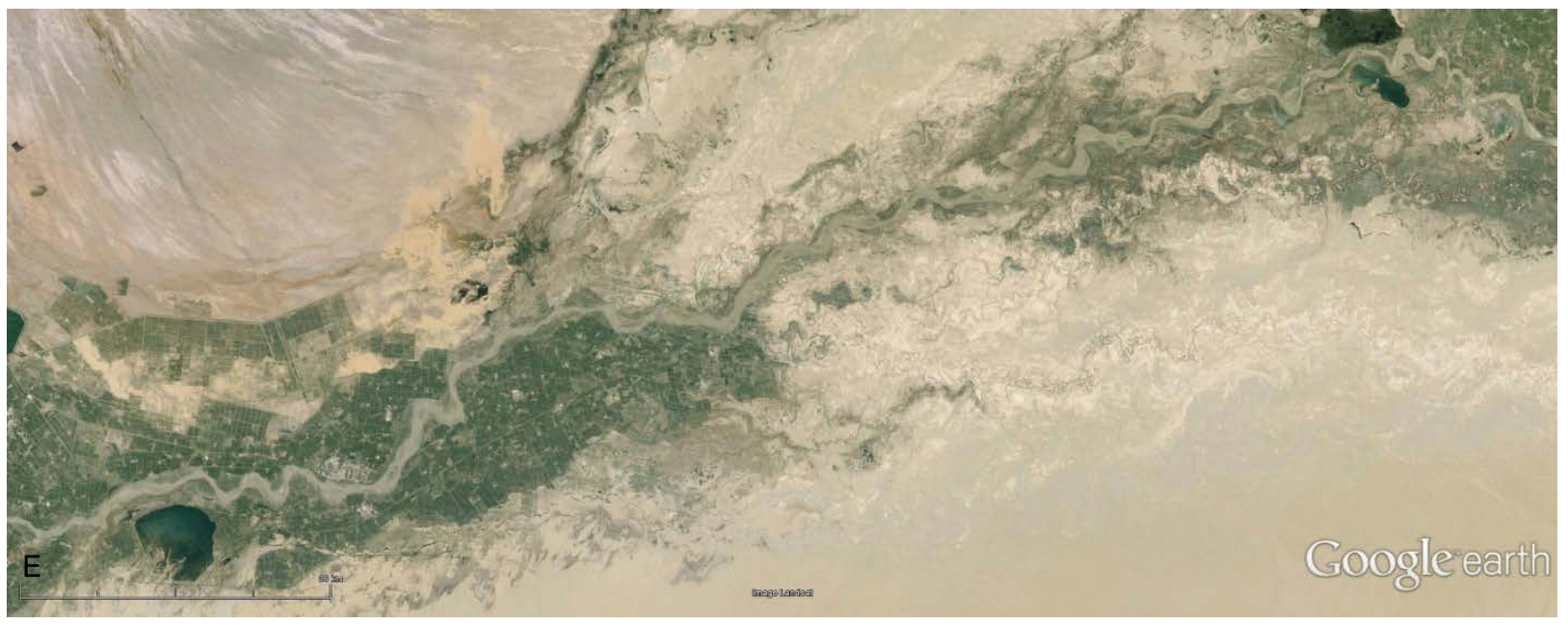

Fig. 1 Examples where fluvial-aeolian interactions are difficult to identify. A) Ushtobe, Kazakhstan $\left(45^{\circ} 34^{\prime} 20.34^{\prime \prime} \mathrm{N}\right.$

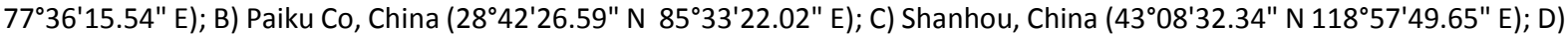
North Panamint valley, America $\left(36^{\circ} 27^{\prime} 49.79^{\prime \prime} N 117^{\circ} 26^{\prime} 55.98^{\prime \prime}\right.$ W); E) Tarim River on the north border of Taklamakan Desert,

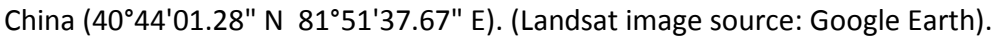


The search methodology started at the margins of dryland areas visually identified within Google Earth. The margins of these areas are where the aeolian and fluvial processes were most likely to meet each other (Bullard and Livingstone, 2002). Identifiable river courses were then traced up and down stream to find places where aeolian dunes interact with river courses. Interactions were identified at a regional scale, where the interaction within one single river catchment will be recorded as one case (Fig. 2A, B). On some very long-course rivers, that may cross more diverse landscapes or even different climatic zones, examples were selected where they were not located in the same region or where there were clear examples of different interaction types at different location (Fig. 2C). However, in some locations many small streams flow down from mountains and dissipate into dune fields. To prevent double counting such cases were recorded as a single example as these small streams are all located in the same region and all exhibit similar behavior in interacting with the local aeolian process (Fig. 2D). To additionally reduce uncertainty wherever examples are located, the location must be in areas outside of the influence of obvious human activity. As a result many places with fluvial and aeolian interactions were excluded from the final dataset because of the high population densities found along many rivers, for example, the Tarim River on the north border of Taklamakan Desert in China (Fig. 1E).

At each site, several other basic variables were recorded: the channel type, the dune type, the channel flow direction and the aeolian transport direction. These allowed further analysis of possible causes of different types of fluvial/aeolian interaction. The following sections describe the classification method, as well as how channel pattern, dune type, channel flow direction and wind direction were determined. 

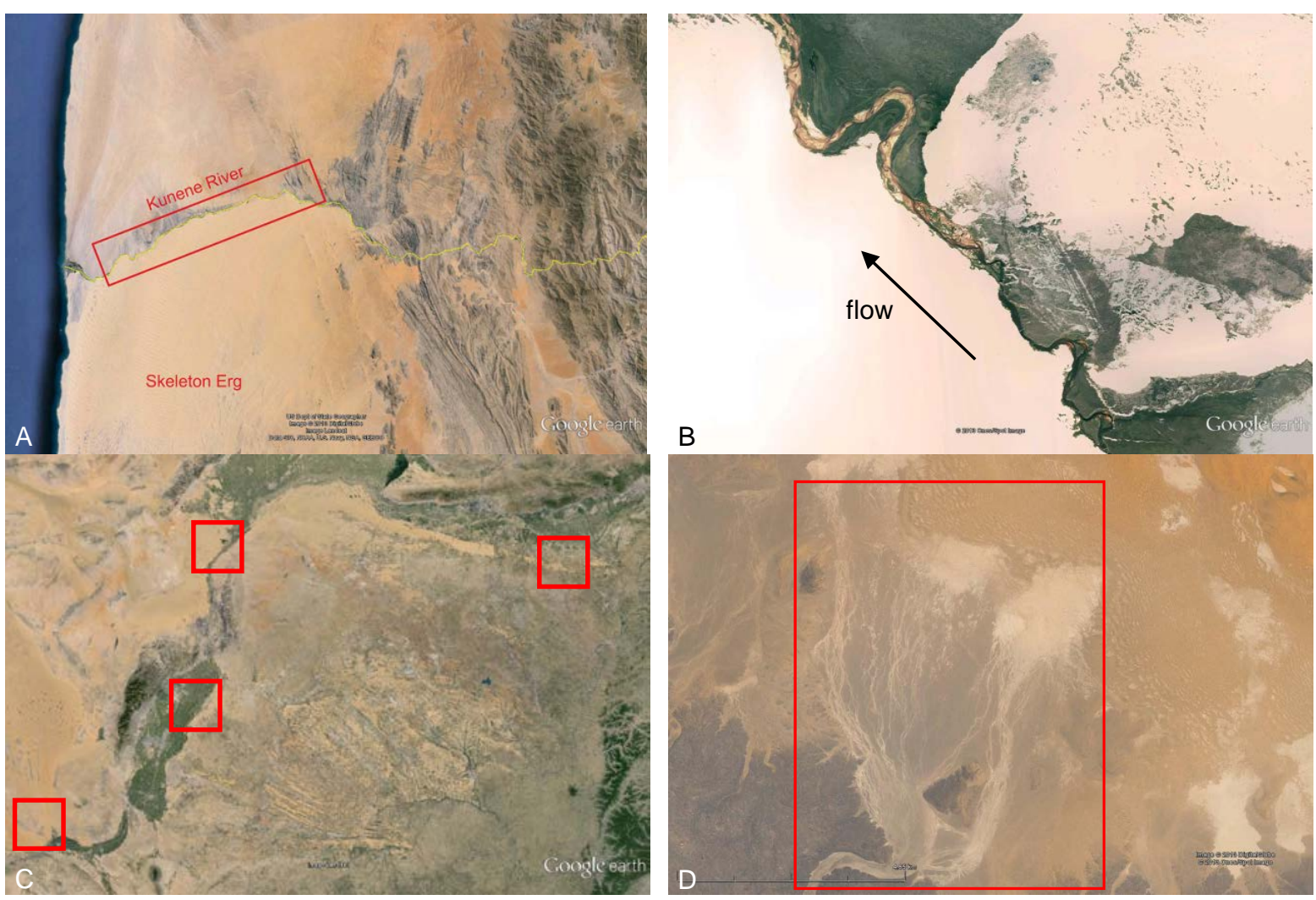

Fig. 2 Examples of the identification of study sites (highlighted in the rectangle). A) Downstream region of the Kunene River

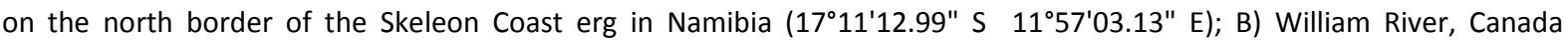
$\left(59^{\circ} 01^{\prime} 40.19^{\prime \prime} \mathrm{N} 109^{\circ} 10^{\prime} 58.41^{\prime \prime} \mathrm{W}\right)$; C) Four study sites were selected along the Yellow River in China which are located separately at Gansu $\left(37^{\circ} 27^{\prime} 17.09^{\prime \prime} N 104^{\circ} 58^{\prime} 52.45^{\prime \prime} E\right)$, Ningxia $\left(38^{\circ} 42^{\prime} 13.11^{\prime \prime} \mathrm{N} 106^{\circ} 36^{\prime} 16.14^{\prime \prime E}\right)$, Neimenggu $\left(40^{\circ} 04^{\prime} 49.78^{\prime \prime} \mathrm{N}\right.$ $106^{\circ} 44^{\prime} 43.07^{\prime \prime} \mathrm{E}$ and $\left.40^{\circ} 07^{\prime} 51.00^{\prime \prime} \mathrm{N} 111^{\circ} 18^{\prime} 54.10^{\prime \prime} \mathrm{E}\right)$; D) Streams on the edge of Erg Atafaitafa in Algeria $\left(26^{\circ} 17^{\prime} 09.21^{\prime \prime} \mathrm{N}\right.$ 645'52.67" E). (Landsat image source: Google Earth).

\subsection{Interaction type classification}

As we aim to categorize fluvial-aeolian interaction types at a range of regional and local scales the criteria necessary for the classification need to be considered carefully. These categories should be:

a) Comprehensive and universal- the categories should account for most of the interaction types that can be identified visually and be applied widely;

b) Reflect the processes in operation; and 
c) Simple and, where possible, compatible with existing fluvial and aeolian classifications.

To establish the categories, a scoping survey was carried out identifying locations where fluvial activity has an impact on aeolian processes and landforms (e.g. dune size and pattern), and where aeolian activity triggers a response in the fluvial regime (e.g. channel change including width, length and location), as well as areas where the two systems are codependent. Following this, the six most common modes of interaction were classified and are outlined below in Table 1 and illustrated in Fig. 3(a-f). The interpretation of the satellite images and the mode of classification is subjective, and limitations associated with this process are considered further in the discussion. 


\begin{tabular}{|c|c|}
\hline Interaction type & Geomorphologic characteristics \\
\hline $\begin{array}{l}\text { Fully fluvial } \\
\text { dominant }\end{array}$ & $\begin{array}{l}\text { Dunes are located on only one side of river, with the river acting as a barrier to dune } \\
\text { movement }\end{array}$ \\
\hline $\begin{array}{l}\text { Mostly fluvial } \\
\text { dominant }\end{array}$ & $\begin{array}{l}\text { Dunes are present on both sides of river but are smaller on the downwind side of the } \\
\text { river due to sediment depletion. The river flows through the dune field with little or no } \\
\text { change in the channel course. }\end{array}$ \\
\hline Balanced & $\begin{array}{l}\text { The river flows through the dune field and dunes of similar size can be observed on } \\
\text { both sides of the river channel. There are no obvious changes in channel } \\
\text { width/length/location and dune type/size. }\end{array}$ \\
\hline $\begin{array}{l}\text { Mostly aeolian } \\
\text { dominant }\end{array}$ & $\begin{array}{l}\text { River flows through the dune field but notable changes on channel } \\
\text { width/length/location are observed. The channel may be pushed across in the direction } \\
\text { of aeolian transport and /or partially obstructed by dunes. }\end{array}$ \\
\hline $\begin{array}{l}\text { Fully aeolian } \\
\text { dominant }\end{array}$ & $\begin{array}{l}\text { Dunes block or terminate the river. The river flows into the dune field but its path is } \\
\text { blocked by sand dunes preventing it from flowing further. }\end{array}$ \\
\hline Alternating & $\begin{array}{l}\text { A system where the dominance alternates between fluvial and aeolian. e.g. Dunes may } \\
\text { occupy the dry ephemeral/intermittent river bed during dry seasons but are eroded by } \\
\text { water flow during wet seasons. }\end{array}$ \\
\hline
\end{tabular}

1) Fully fluvial dominant: When fluvial processes dominate the development of landscape, stream power is great enough to transport all of the sediment input from the dunes (Fig. 3a). Because of this interception of aeolian sands by the river, the aeolian sand supply is greatly decreased on the downwind side of river to the extent that no obvious dunes could be developed. The channel acts as a boundary preventing the onward dune movement.

2) Mostly fluvial dominant: As the influence of fluvial processes diminishes in relation to aeolian the interactions become more balanced. Here, rivers have the power to pass 
through the dune field but are unable to remove all the sediment input from the aeolian system thus allowing some onward dune migration. The resulting landscape is typified by dune fields on both sides of the river but dunes on downwind side of the river are smaller or the dune type changes due to reduced sediment supply (e.g. from transverse ridges to barchans) (Fig. 3b).

3) Balanced: The forces between fluvial and aeolian processes become close to equal so no one process dominates. Therefore, the landscape appears to be in a state of balance where both fluvial and aeolian processes operate without interruption (Fig. 3c). Here, the river manages to pass through a dune field, with or without change, whilst the dune fields on both sides of the river exhibit parallel development, e.g. similar dune size and pattern.

4) Mostly aeolian dominant: Here, the power of aeolian action increases above that of fluvial action and the sand dunes can partially dam the river channel and/or divert the channel path (Fig. 3d). From the images this could be observed where the channel becomes narrower when it was dammed or wider when it was diverted to more open space thus changing its location and length. The dune size and type typically shows little or no change on the downwind side of the river.

5) Fully aeolian dominant: As aeolian process become more dominant the river course can be terminated by a dune field and the landscape becomes aeolian dominant (Fig. 3e). The landscape dominated by this interaction type can be clearly observed in the field that the river's course is completely obstructed by the dunes.

6) Alternating: Where ephemeral or intermittent rivers flow across a dune field, the predominant processes can then alternate between aeolian and fluvial. For example, in dryer seasons, when river flows are low or zero, the aeolian process can deposit in 
the channel, in some cases covering the channel with aeolian features such as dunes. When wetter seasons arrive, flood events can erode part or all of the aeolian features in the channel or the channel location can be diverted because of the dunes obstructing the rivers path (Fig. 3f). At many study sites, the alternating type can by identified directly from satellite images where dunes were observed located on channel course, for example, the dunes in the upper left corner in the image of Fig. 3f.

\subsection{Channel pattern}

At each location, channel pattern was recorded as this provides information on the river characteristics and behaviour. For example, the relationship between channel form and sediment load may be important to ascertain aeolian sediment inputs on fluvial systems by changing the channel pattern (Leopold and Wolman, 1957; Schumm, 1985). From a scoping study we determined that the most frequently occurring categories of channel patterns were Straight, Meandering, Wandering and Braided which form the main categories recorded. Some examples of different channel patterns, for example anabranching, anastomosing, and distributive were classified into the group Others because of their low occurrence.

\subsection{Dune field pattern}

Satellite imagery limits the amount of morphological information available when classifying dunes. Therefore, four dune categories were adopted during the survey, including Transverse ridges, Barchans, Longitudinal ridges and Stars. These dune patterns are not only readily discernible from satellite images, but aside from star dunes their alignment is related to the dominant or resultant sand transport direction, thus reflecting the wind regime condition 
(Wilson, 1972; Fryberger, 1979; Hunter et al., 1983). Dunes that have low occurrence or those that are not easily identifiable solely from the GE images but can be proved by literature were classified into a fifth category of Others (which included oblique, parabolic, reversing, dome, nebkhas, lunettes, and source bordering dunes) (Rendell et al., 2003; Han et al., 2007; Maroulis et al., 2007).
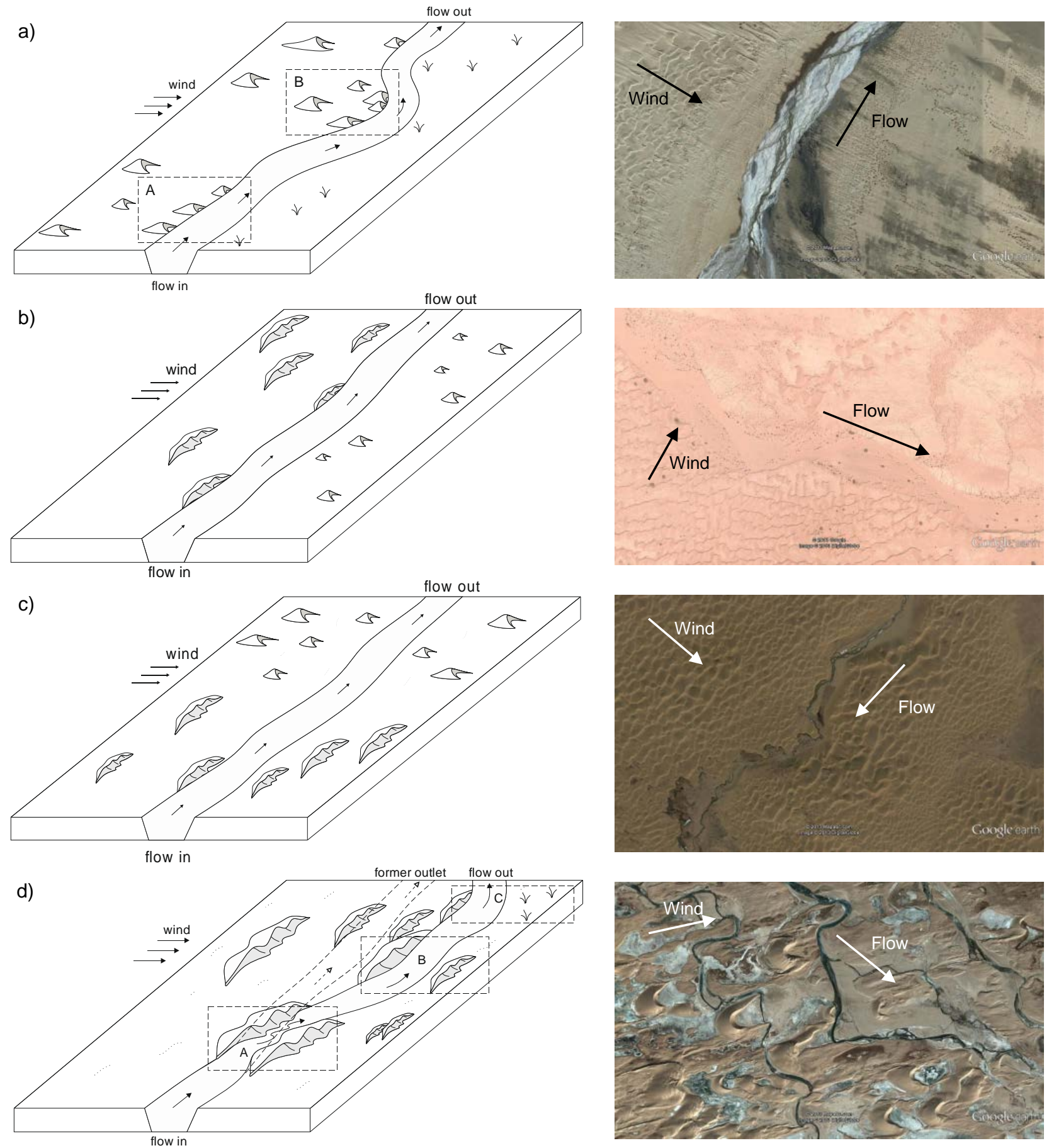

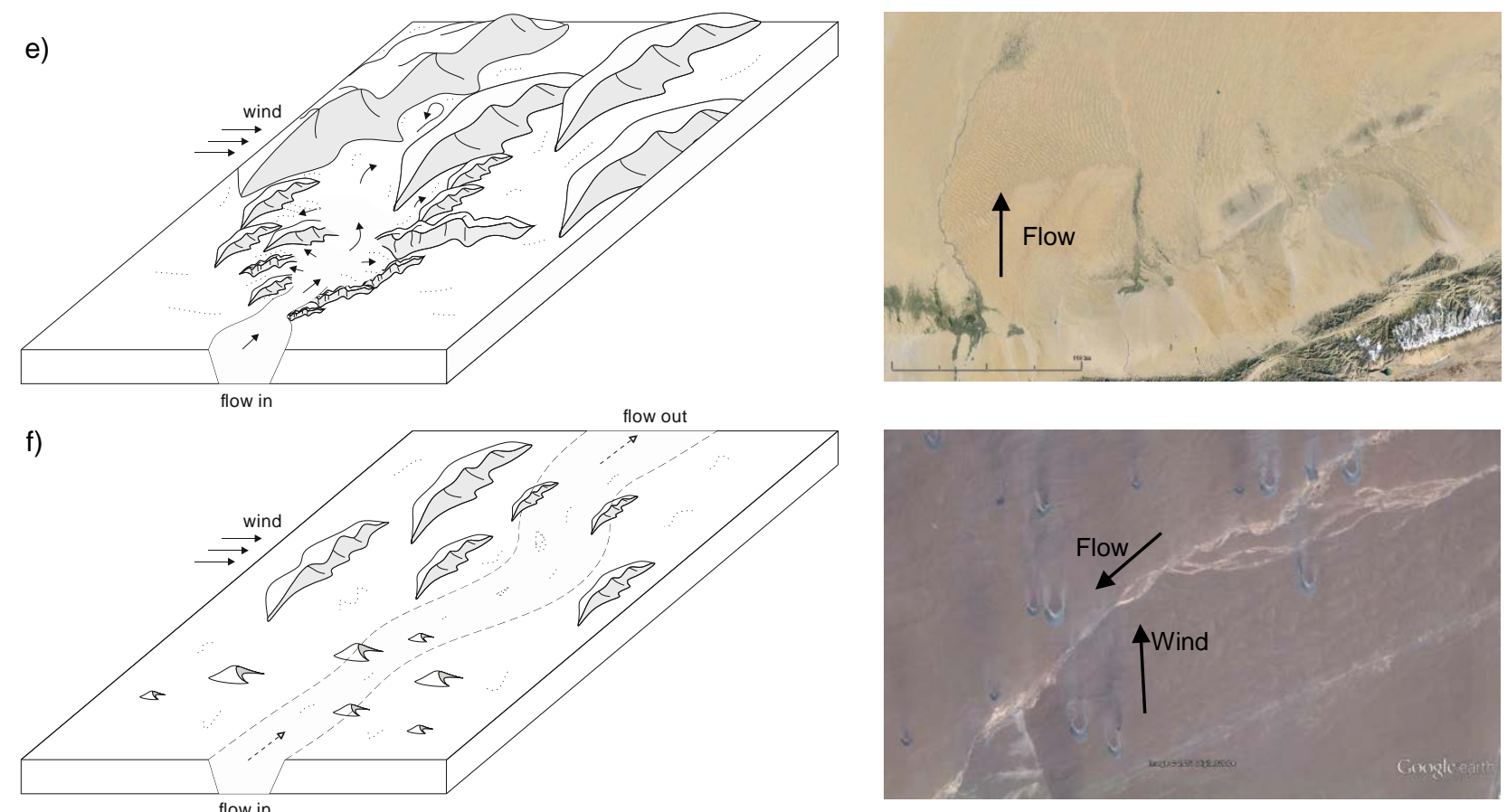

Sand

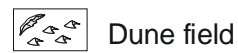

None-dune field

River channel

Abandoned river channel

Fig. 3 Diagrams of different types of interaction. a) Fully fluvial dominant. In the diagram, area A - a location where the river stops dune movement without changing the channel location and type; Area B - a location where the river stops dune movement but the channel location is pushed in downwind direction. The example shows the Tuolahai River in China, the inward dunes moving from NW while the river flows to the NE. There are dunes present on NW side of river whereas only bare surface or sand sheet exhibit on NE side of river, and there are no significant changes on channel pattern and location $\left(36^{\circ} 40^{\prime} 22.88^{\prime \prime} \mathrm{N} 94^{\circ} 29^{\prime} 08.16^{\prime \prime} \mathrm{E}\right)$; b) Mostly fluvial dominant. The example shows a river in Morroco, there are dense transverse dunes on the SW side of the channel moving towards the river, whereas only barchans are sparsely distributed on the NE side of channel moving away from the river (31 $\left.32^{\prime} 53.04^{\prime \prime} \mathrm{N} 4^{\circ} 30^{\prime} 50.88^{\prime \prime} \mathrm{W}\right)$; c) Balanced. The example is located in Yellow River watershed in China, the uniform sizes of transverse ridges present on both sides of the river bank $\left(35^{\circ} 34^{\prime} 46.91^{\prime \prime} \mathrm{N} 101^{\circ} 01^{\prime} 01.23^{\prime \prime} \mathrm{E}\right)$; d) Mostly aeolian dominant. In the diagram, area A - dunes dam the river course, area B dunes divert the river course, area C - dunes push the river course to the margin. The example is located in the Himalaya, China, where barchans moving towards the NE dam, divert the channel and thereby change the channel location when crossing the streams $\left(29^{\circ} 55^{\prime} 40.12^{\prime \prime} \mathrm{N} 83^{\circ} 32^{\prime} 35.12^{\prime \prime} \mathrm{E}\right)$; e) Fully aeolian dominant. Examples illustrated are located on the south margin of Taklamakan desert, China, streams flow down from the mountain range into the dune field but have been dammed, diverted and finally diminished with distance (37 $\left.33^{\prime} 09.83^{\prime \prime} \mathrm{N} 84^{\circ} 18^{\prime} 30.55^{\prime \prime} \mathrm{E}\right)$; f) Alternating. The example is located in La Joya, Peru. Barchans moving towards north are located on both sides of the ephemeral river bank and even in the channel with no significant change in size so that the dunes may cross the channel during dry season and are eroded when floods occur in the channel (16 $39^{\prime} 08.44^{\prime \prime} S 71^{\circ} 51^{\prime} 23.02^{\prime \prime}$ W). (Landsat image source: Google Earth). 


\subsection{River flow/net aeolian sand transport direction and meeting angle}

The river flow direction is measured as the direction along a straight line from the river inflow point to the outflow point within the scale of study area as opposed to the river thalweg (as illustrated in diagrams and GE images in Fig. 3). This allows us to assess the general flow direction across the region of study as opposed to specific directions at individual spots.

The net aeolian sand transport direction is the resultant dune drift potential vector which is identified by the dune pattern or dominant wind regime in study area. For example, a barchan dunes migration direction is approximately parallel to the symmetry axis line from its convex point to the horns. The sand drift direction of transverse ridges is perpendicular to its crest line, whilst longitudinal dunes mainly form in wide unimodal or bi-directional wind regimes so the resultant or vector sum transport direction is approximately parallel to the dunes. These data were not gathered for Star dunes due to their formation being controlled by multiple wind directions. Additionally, where available, information on local wind directions were obtained from existing studies.

The observed flow and net aeolian sand transport direction were classified into 16 evenly distributed directions categories ranging from $0^{\circ}$ to $180^{\circ}$ plus one more category of "multidirection" to account for features (such as star dunes) that are associated with a multidirectional or complex wind regime.

The Meeting angles between flow and net aeolian sand transport, were also grouped into the same categories as flow/net aeolian sand transport direction (Fig. 4A), and can be described 
mainly as directions with both aeolian and fluvial flow $\left(\left[0^{\circ}, 67.5^{\circ}\right)\right.$, Fig. $\left.4 \mathrm{~B}_{1}\right)$, perpendicular $\left(\left[67.5^{\circ}, 112.5^{\circ}\right]\right.$, Fig. $\left.4 B_{2}\right)$ or against $\left(\left(112.5^{\circ}, 180^{\circ}\right]\right.$,Fig. $\left.4 B_{3}\right)$.
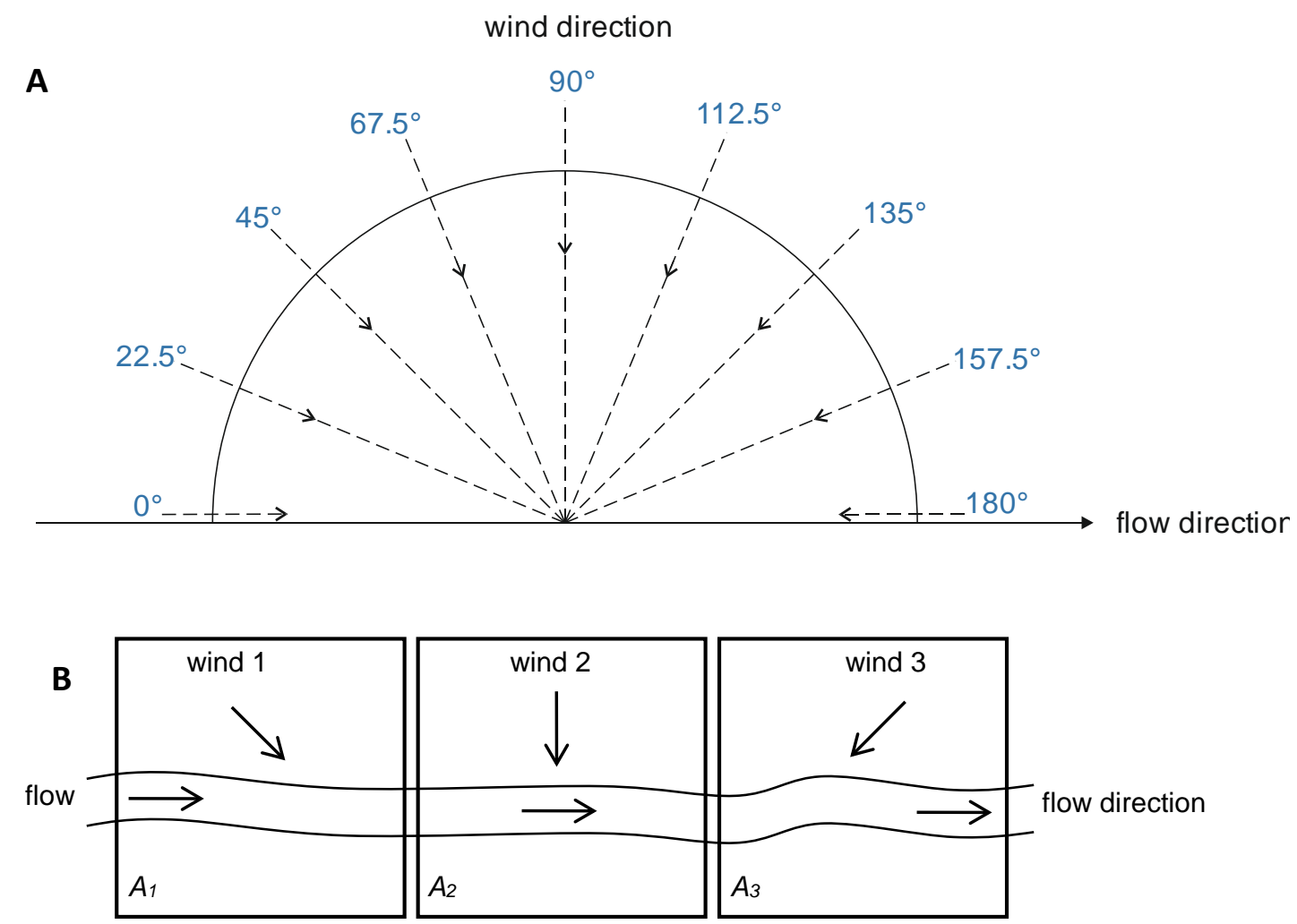

Fig. 4 Illustration of the meeting angle between flow and net aeolian sand transport direction.

These directional categories were chosen to reflect the sample size and to reduce error inherent in the measurement and estimation of the aeolian and fluvial flow angles. For example the angles could be continuously recorded from 0-180 degrees, but with a limited number of sites this would leave a patchy data-set, with some angles having no recorded examples. Binning the direction results into these categories makes analysis clearer and simpler, allows us to account for errors in the measurement of the angles yet enables us to make additional analyses by combining some of the categories (see Table 2). 


\section{Results}

A total of 230 globally distributed study sites were identified where river and dunes were observed to be interacting with each other (Fig. 5). The majority of these sites are located in Africa, Asia and Australia, with additional sites at the west coast of South America and in North America. Applying the categories described in section 2, the distribution of the categories for each group are presented in Fig. 6 . Some of the categories had a small number of occurrences that were considered insufficient for any statistical analysis. Therefore, these categories were not included in any further analysis. These categories are the channel pattern of Others and the dune type of Star and Others (Fig. 6a, b), the Mult meeting angle category (Fig. 6c) and the interaction type of Alternating (Fig. 6d). The following sections describe relationships observed between these interacting categories.

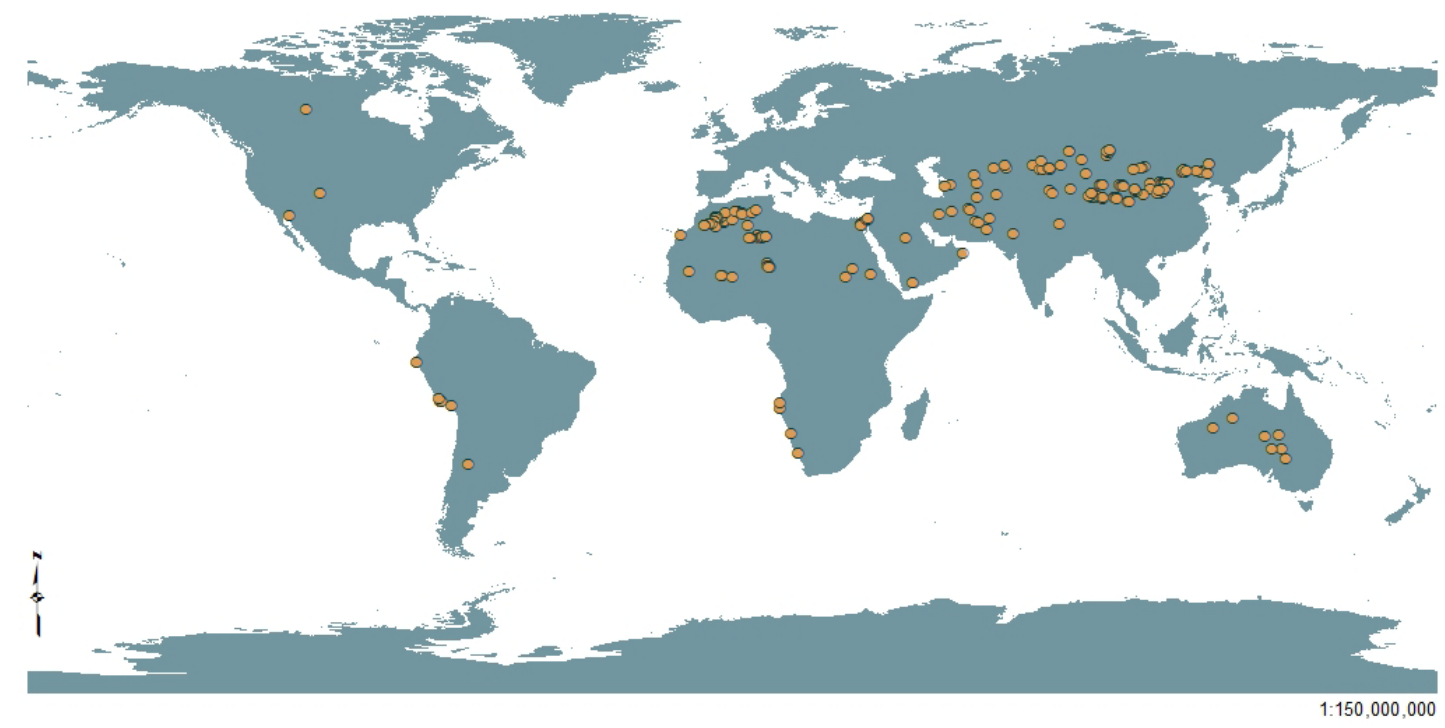

Fig. 5 Location of 230 study sites.

(a) 

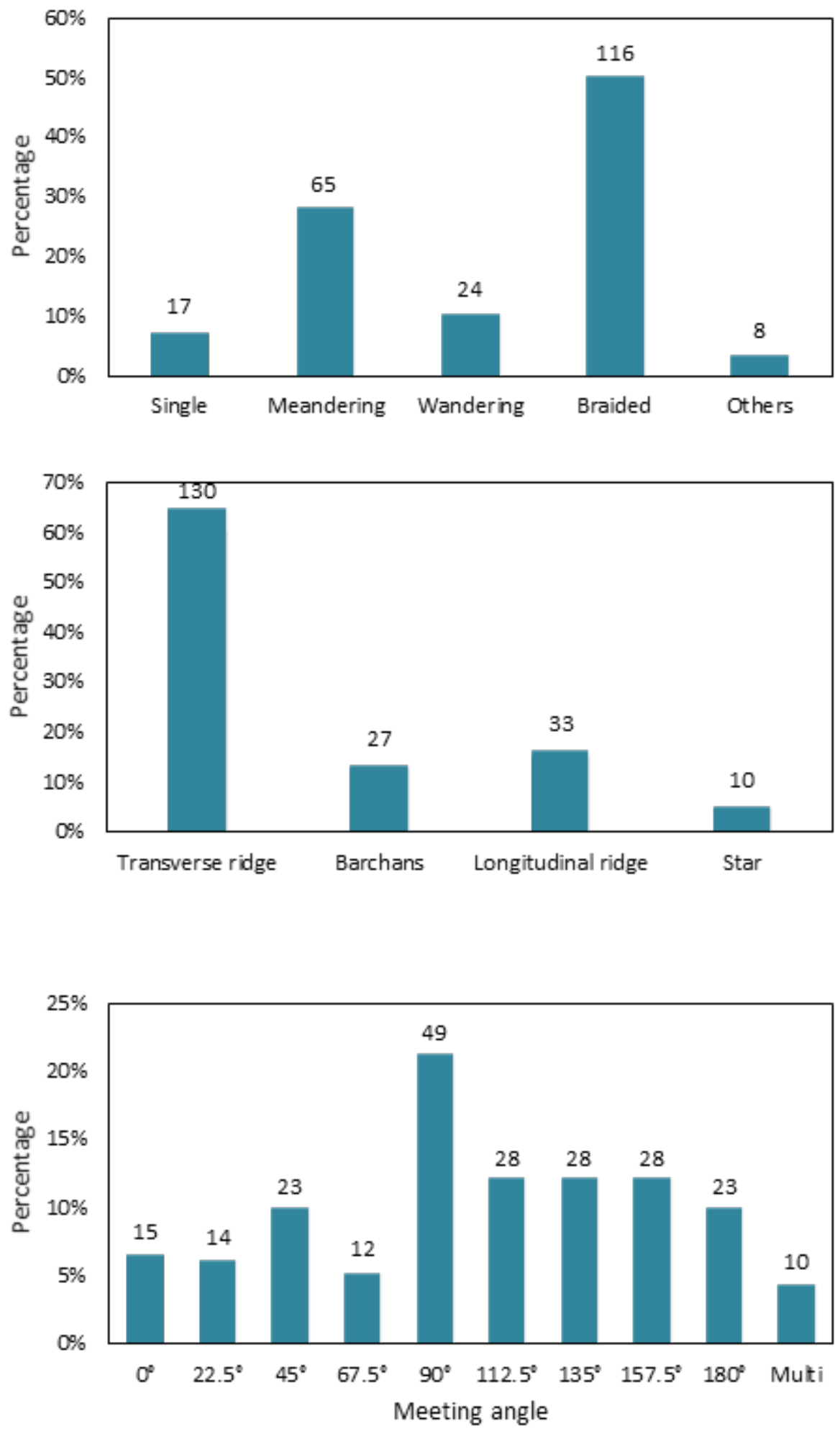


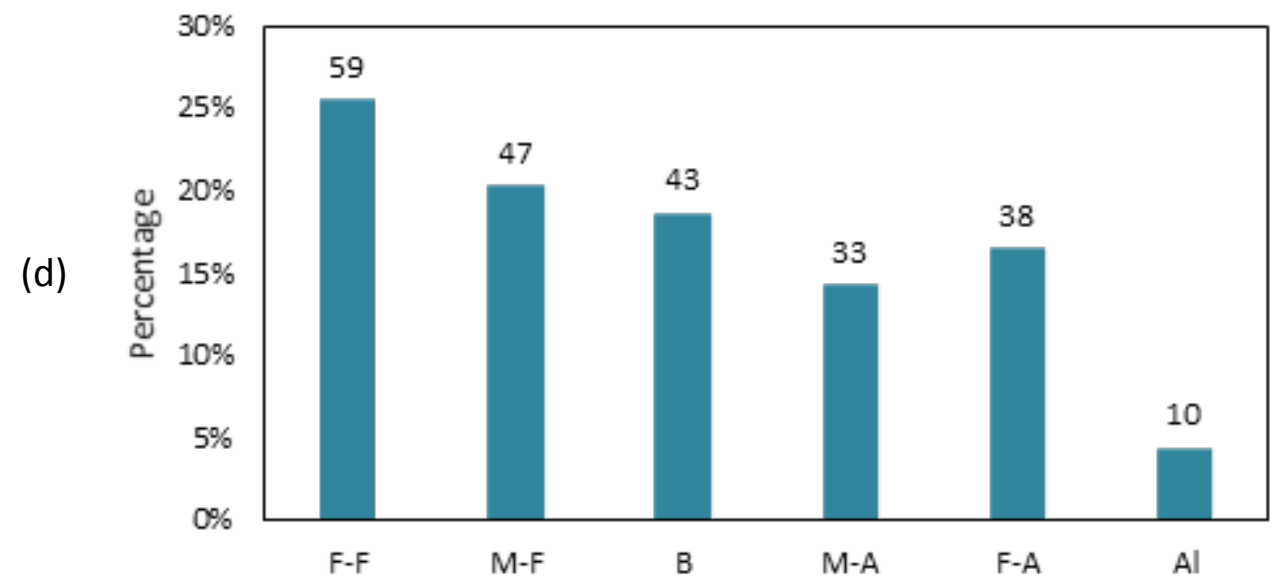

Fig. 6 Categories distribution in each surveyed factor group, count numbers of each class is labelled. (a) Percentage of all channel patterns; (b) Percentage of all dune types; (c) Percentage of all meeting angle categories; (d) Percentage of all interaction types, where on the $\mathrm{x}$-axis, $\mathrm{F}-\mathrm{F}=\mathrm{Fully}$ fluvial dominant, $\mathrm{M}-\mathrm{F}=$ Mostly fluvial dominant, $\mathrm{B}=\mathrm{Balanced}, \mathrm{M}-\mathrm{A}=\mathrm{Mostly}$ aeolian dominant, $\mathrm{F}-\mathrm{A}=$ Fully aeolian dominant and $\mathrm{Al}=$ Alternating.

\subsection{Dune type vs channel pattern}

The relationship between dune type and channel pattern is shown in Fig. 7. Although Transverse ridges have the greatest occurrence among all dune categories, a similar distribution of channel patterns can be observed for every dune category - with Braided channel patterns having the most frequent occurrence followed by Meandering, Wandering and then Straight river patterns. A Chi-square test on the samples indicates that there is no significant association between channel pattern and dune type $\left(\chi^{2}=12.592, d . f .=6, p>\right.$ $0.05)$. 


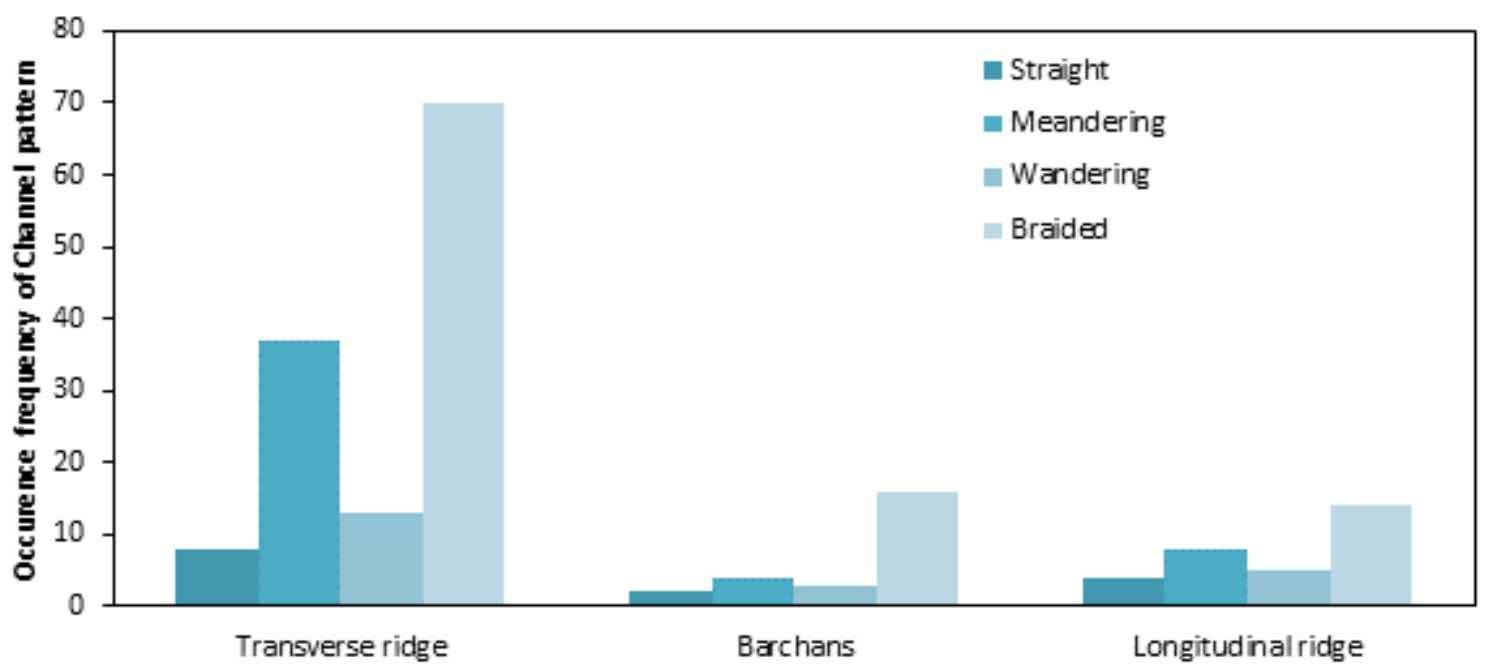

Fig. 7 Frequency of channel patterns interacting with different dune types. Percentage of dune type is also indicated.

\subsection{Interaction type vs dune type / channel pattern}

No significant relationship between interaction type and dune type was found with our field data $\left(\chi^{2}=15.507\right.$, d.f. $\left.=8, p>0.05\right)$. However, quite different distributions of the interaction types can be observed between the different dune categories (Fig. 8), especially between Barchans and Longitudinal ridge dunes. For Barchans, there are very few Balanced interaction types with interactions being dominated either by fluvial or aeolian action. Conversely for the Longitudinal ridge category there is the inverse distribution of the interaction type for Barchan dunes, with a high proportion in the Balanced interaction type, and a low proportion in fluvial/aeolian dominant interactions. 


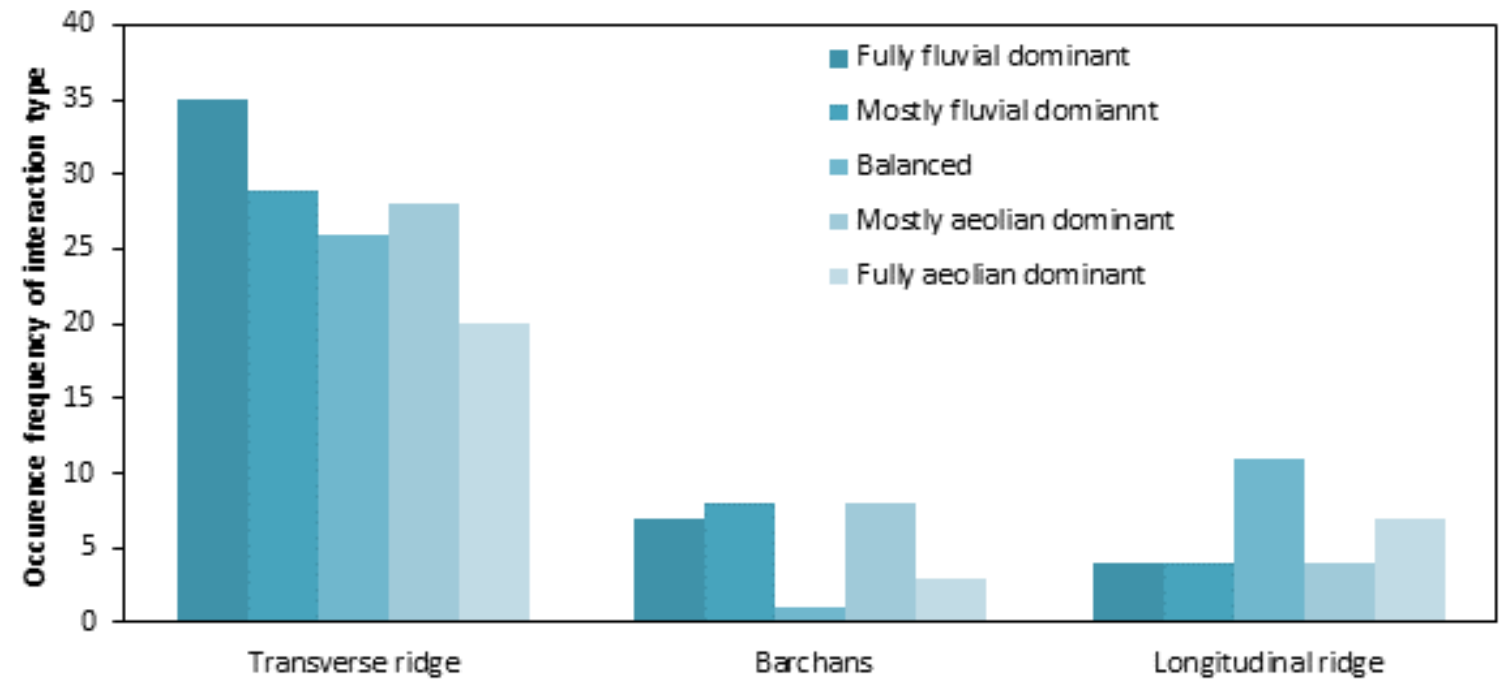

Fig. 8 Frequency of interaction types in each dune type category.

However, there was a significant relationship between interaction type and channel pattern (Fig. 9) $\left(\chi^{2}=21.026, d . f .=12, p<0.05\right)$. With Straight and Meandering channels, there was a higher frequency of the Balanced interaction type but less for all the other Interactions. Conversely for Wandering and Braided channel categories, the Balanced interaction type had the lowest observed frequency.

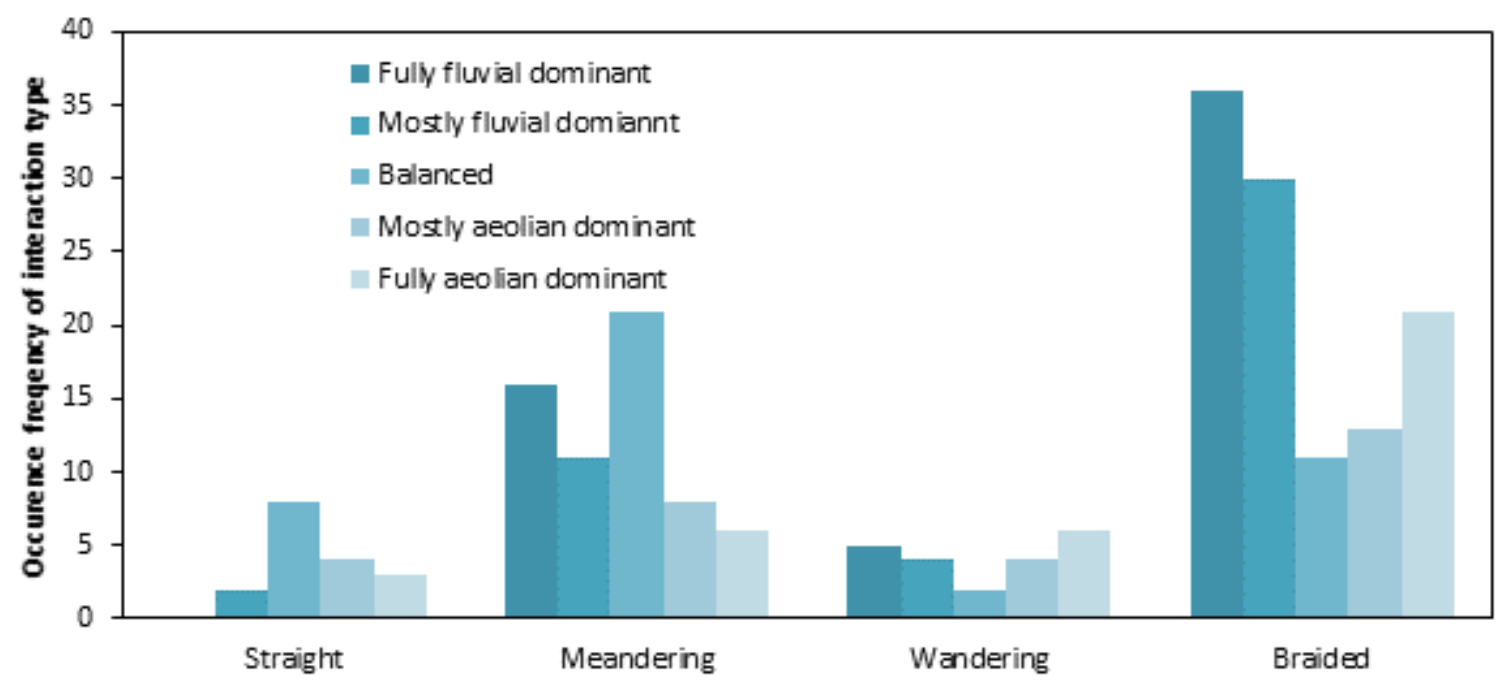

Fig. 9 Frequency of channel pattern and interaction type in each pattern category of channels. 


\subsection{Meeting angle vs dune type /channel pattern.}

Fig. 10 shows that transverse dunes (Transverse ridges and Barchans) are most likely to meet the river at right angles, whereas Longitudinal ridges are more likely to be parallel to the river direction $\left(\left[0^{\circ}, 45^{\circ}\right),\left[157.5^{\circ}, 180^{\circ}\right]\right)$. A Chi-square test further supports this, with a significant relationship between dune type and the meeting angle $\left(\chi^{2}=26.296, d . f .=16, p<0.05\right)$.

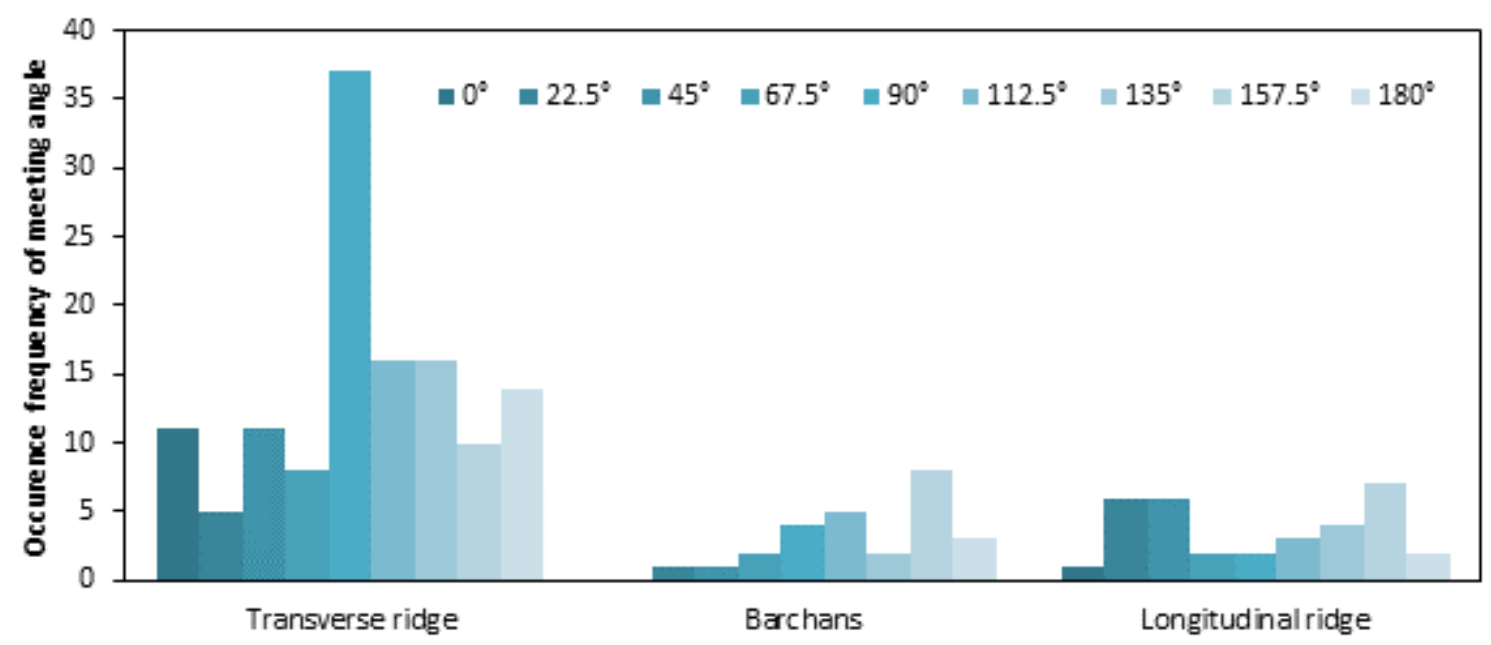

Fig. 10 Frequency of meeting angle with different dune type.

In contrast, there is no significant relationship between channel pattern and meeting angle $\left(\chi^{2}=12.592, d . f .=6, p>0.05\right)$. Though in Fig. 11, Straight rivers appear to interact with dunes at smaller angle, whereas the Meandering rivers are more likely to be perpendicular or parallel to the dune movement direction. The Wandering and Braided river patterns have higher occurrences at $90^{\circ}$ and above interaction angles. 


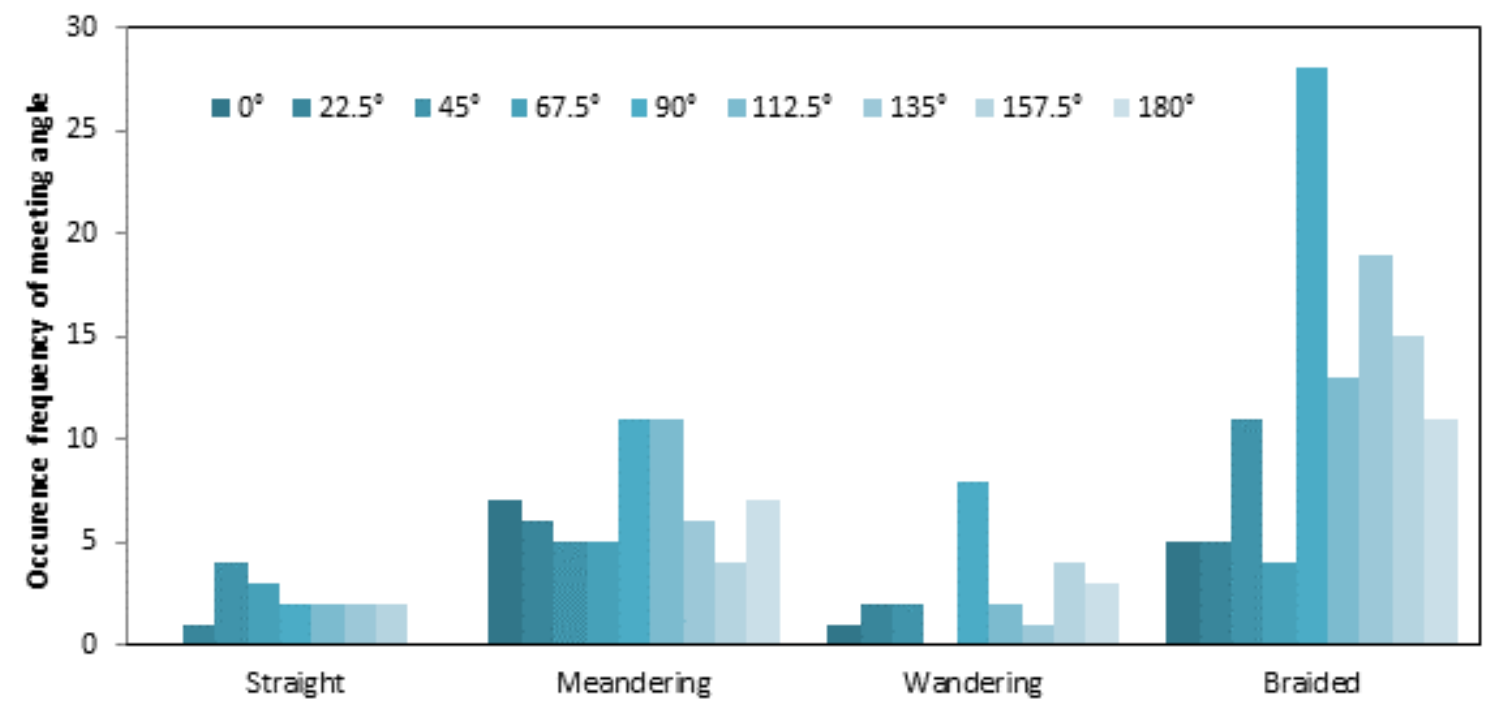

Fig. 11 Frequency of meeting angle with different channel pattern.

Tests with various bin sizes showed that the bin sizes of the meeting angles had little influence on the overall distributions or the significance of the Chi-square tests. However, given the sample size, combining some of the categories can help to further simplify the results, for example, the combined meeting angle categories illustrated in Table 2.

\subsection{Interaction type vs meeting angle}

The relationship between interaction type and meeting angle (Fig. 12) displays an irregular distribution pattern, however, a Chi-square test shows the interaction type is significantly associated with meeting angle $\left(\chi^{2}=46.194, d . f .=32, p<0.05\right)$. Despite this, we cannot identify whether the interaction type is determined by meeting angle of the interaction or vice versa. But from Fig. 12 we can observe that fully/mostly fluvial and aeolian dominant interactions have similar distributions of meeting angles that are low for angles from $0^{\circ}$ to $90^{\circ}$ but higher for $112.5^{\circ}-180^{\circ}$, whereas in Balanced situations the rivers and dunes are more 
likely to meet at $0^{\circ}-67.5^{\circ}$ followed by $112.5^{\circ}-180^{\circ}$, but less likely to meet at right angles (Table 2).

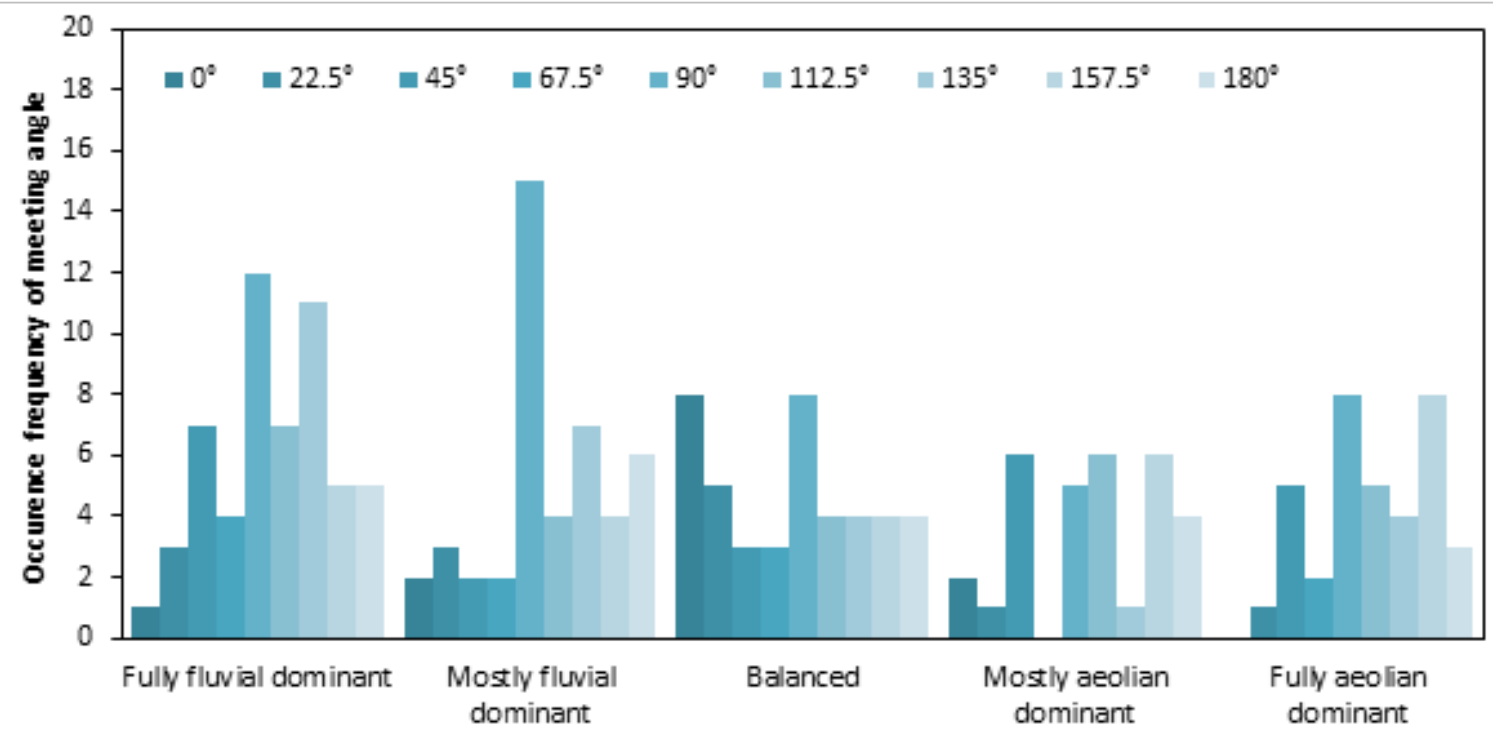

Fig. 12 Frequency of interaction type and the distribution of meeting angles in each group of interaction type.

Table 2 Proportions of combined meeting angles in combined categories of interaction types.

\begin{tabular}{|c|c|c|c|c|}
\hline Dominant process & Combined processes & $0^{\circ}-67.5^{\circ}$ & $90^{\circ}$ & $112.5^{\circ}-180^{\circ}$ \\
\hline Fluvial predominant & Fully and mostly fluvial dominant & $24 \%$ & $27 \%$ & $49 \%$ \\
\hline Balanced & Balanced & $44 \%$ & $19 \%$ & $37 \%$ \\
\hline Aeolian predominant & Fully and mostly aeolian dominant & $25 \%$ & $19 \%$ & $55 \%$ \\
\hline
\end{tabular}

\section{Discussion}

The results show significant relationships between aeolian and fluvial systems and these are summarised graphically in Fig. 13. Here factors connected by double arrows show a significant and a dashed line reflects no association. For example, Dune type has a good relationship with Meeting angle but no significant relationship with Interaction type. 


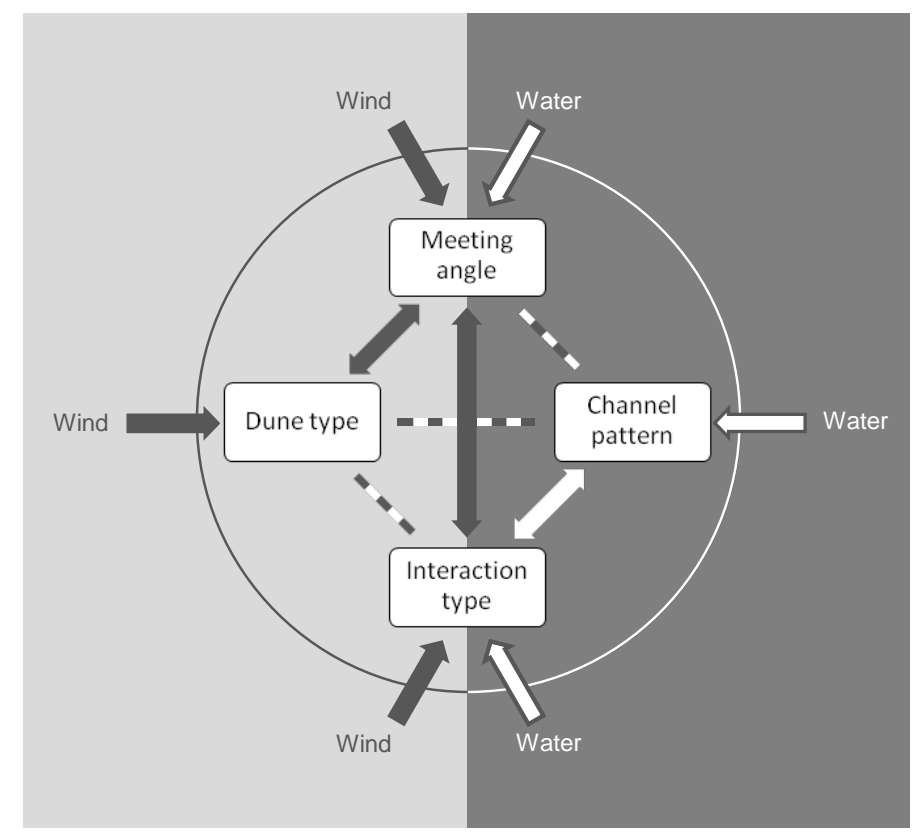

Fig. 13 Conceptual diagram showing the interactions and significant relationships between fluvial and aeolian systems.

The most interesting relationships are associated with influences on channel pattern and the dune type/interaction type. Braided channel patterns are associated with active sediment erosion and deposition and often found in areas of high sediment supply. Therefore, it is perhaps unsurprising that these were the most commonly observed type of river in this study - as aeolian activity would introduce sand into the fluvial system. Following this assumption we expected to find a larger proportion of braided/wandering streams associated with faster moving, more active dune types (transverse and barchans). But the distribution of channel types was remarkably similar for all dune types (Fig. 7) and no significant relationship was found. This suggests that enhanced sediment input from aeolian sources may not be the instigator of change of channel pattern, as has previously been suggested by others (Huisink, 2000). However, there was a significant relationship between channel pattern and the interaction type (Fig. 9) where the highest frequency of interactions for Straight and Meandering channels was related to the Balanced type, and Wandering and Braided patterns were most likely associated with either fully/mostly fluvial or aeolian dominated. This 
indicates that Wandering and Braided types are more likely to develop in where there is a dominance of either aeolian or fluvial processes but not in a balanced situation. This is understandable, as more dynamic channel patterns (Wandering and Braided) were associated with imbalanced systems and lower energy (Meandering and Straight) with those in balance indicating a level of stability.

There was also no significant interaction between channel pattern and interaction meeting angle (Fig. 11). This is an interesting negative result, as we would expect systems where sand transport directions were perpendicular to the river direction would deposit proportionately more sediment into a river than those where the direction was parallel. By running perpendicular to each other, the fluvial and aeolian systems maximise the contact area between them (length of river bank exposed to aeolian transport), thus increasing the potential for transfer for sediment from aeolian to fluvial system. Therefore, we expected sediment added from aeolian sources from perpendicular interactions would lead to a dominance of Braided/Wandering (more active) channel patterns and parallel interaction angles leading to less active (Straight/Meandering) patterns.

However, there was evidence for this perpendicular effect and a contrasting interaction with parallel river flow/net aeolian sand transport directions when looking at the meeting angle, interaction type and dune type together. Transverse ridges and barchans are active dune forms and mostly they meet rivers at angles in the range of $90^{\circ}$ and $135^{\circ}$ (Fig. 10). These dune types and interaction angles are also associated with systems that are not in balance (Fig. 8, 12) having either a fluvial or aeolian dominance. In contrast, longitudinal dunes are less dynamic and many extend in parallel with the channel direction (Fig. 8, 10). This minimizes 
the contact area between the systems contributing to a balanced situation between fluvial and aeolian process. This suggests there may be some self-organisation operating between dune type and river flow direction. In addition, longitudinal dunes are less active than crescentic dunes, further reducing the available sediment that could be transported into the river - thus contributing to a low impact interaction between fluvial and aeolian systems.

This raises the question as to whether parallel and perpendicular interactions between dunes and rivers are due to fate (the existing topography and wind direction) or is there a selforganisation within some dune/river systems? This may, for example, mean that rivers crossing dune fields perpendicular to the net sand transport direction find it more efficient to be pushed or diverted into flowing with the aeolian sand transport direction (where topography allows). Such an interaction is difficult to ascertain without a time series of the two systems interaction, but we can see evidence of this in some field examples. For example Bourke and Pickup (1999) noted that in the Todd River, Australia longitudinal dunes were aligned with the channel pattern. However, it is likely that this interaction will always be one sided, as while deposited sand can alter slopes forcing rivers to take new directions, rivers cannot easily influence the direction of wind driving the aeolian transport.

Looking at the overall balance between fluvial and aeolian dominant systems (Fig. 6d) there is a greater number of sites that are fully fluvial dominant compared to fully aeolian dominant ( $26 \%$ to $17 \%)$. This is also reflected in the next categories of mostly fluvial dominant and mostly aeolian dominant ( $20 \%$ and $14 \%$ respectively). However, these are also be governed by the strength and duration of the wind and water flows which we have not determined in 
this study. Therefore, whilst the results indicate a greater frequency of fluvial dominance we cannot categorically state that either is greatest.

There are several limitations with our methodology that may have an impact on the findings. Our study, whilst global in scope, may not be comprehensive and areas may have been missed. Additionally, we rely upon the visual identification of aeolian/fluvial features and some of these may be incorrectly identified. To help minimise such errors all data were verified by two people. The local predominant wind regime is calculated by the dune shape and meteorological records where available. However, as we are trying to find the sites outside of human influence often these areas are remote where meteorological records may be limited. Whilst much can be gleaned from satellite images, it can often be difficult to fully determine the context of a site. A good example of this is provided by our exclusion of channel pattern change - where we hoped that changes (e.g. from straight to braided) could be used as an indicator of fluvial/aeolian interactions. Despite apparent changes being observed we excluded these as the causes of channel pattern formation are complex and involve interactions of multiple factors, (including variables of topography, channel geometry, slope, bank stability, flow discharge) that may have alternative causes. Unfortunately, from the satellite images we do not have enough information to exclude the influence of alternative factors, in other words from remote sensing we do not have enough site context. However, even with more field data, Huisink (2000) had difficulty in relating historical channel pattern changes in the Vecht Valley (NL) to single driving factors (i.e. aeolian sediment) due to the influence of climate and vegetation changes. 
The greatest limitation with basing our interpretations on contemporary satellite images is that these represent only a moment in a long history of the interaction at the field site in question. It is quite possible that sites may switch (for example) from being mostly aeolian dominant to mostly fluvial dominant. This makes the Balanced category especially difficult to categorise as this state could be static - or it could be in a transition stage from one interaction type to another. Sequential satellite images could be used (dating back to the first Landsat series in the 1970 's), though this only allows us to look at a comparatively short period from the past, especially when considering the time-scale some dune systems may operate over.

Aeolian and fluvial systems can operate at very different rates and this also makes the interpretation of interactions from snapshot images difficult. Rivers have the capability to change direction (e.g. through avulsion) and move to different courses very rapidly and the destructive nature of large floods can lead to sudden changes (rf.?). Conversely, sand dune movement rates are typically low (in the order of less than $1 \mathrm{~m}$ per year (rf.?)- with some exceptions) and therefore may not be instigators of sudden change. However, river flow (especially in arid regions) can be ephemeral and aeolian action and dune movement (though slower) may be more continuous. Therefore, whilst we have given insight into the static balance between aeolian and fluvial geomorphology, further work is required to investigate the dynamic changes between aeolian and fluvial processes.

\section{Conclusions}

This study shows that aeolian and fluvial interactions are clearly widespread - with our survey finding 230 globally distributed sites. Therefore, we conclude that in many locations aeolian and fluvial process are having a significant impact upon each other - and on the subsequent 
landforms and geomorphology. Four variables were analysed to explore possible relationships between fluvial and aeolian systems, including dune type, channel pattern, meeting angle and interaction types. The data showed that certain channel patterns, dune types and interaction angles are most commonly found when there are fluvial and aeolian interactions (e.g. Braided rivers: 50\%, Transverse ridges and Barchans: $73 \%$, and a perpendicular meeting angle: $21 \%$ ). Significant relationships were found between meeting angle - dune type, meeting angle - interaction type and channel pattern - interaction type. These relationships indicate that active river channel patterns (braided and wandering) are most common where aeolian or fluvial systems dominated but not in more stable balanced situations. No relationship was found between more dynamic crescentic dune systems and active channel patterns indicating that additional aeolian sediment supply may not be affecting channel pattern. Furthermore, longitudinal dunes tended to flow parallel with river direction, whereas more active crescentic dunes were more often found migrating perpendicular to river flow. Finally, all of the results are based on snapshots from what are often dynamic systems and further research is required to investigate how the different rates of aeolian and fluvial processes affect their interaction and the subsequent geomorphology.

\section{Acknowledgements}

The work presented in this paper is a part of the doctoral research of BL who is supported by a joint scholarship provided by the University of Hull and the China Scholarship Council. We would like to thank Andreas Baas and Martin Williams for their comprehensive and insightful reviews which greatly improved the paper. 


\section{References}

Bourke, M.C., Ewing, R.C., Finnegan, D., McGowan, H.A., 2009. Sand dune movement in the Victoria Valley, Antarctica. Geomorphology, 109(3-4), 148-160.

Bourke, M.C., Pickup, G., 1999. Fluvial form variability in arid central Australia. In: A.J. Miller, A. Gupta (Eds.), Varieties of fluvial form. Wiley, Chichester, pp. 249-271.

Bullard, J.E., Livingstone, I., 2002. Interactions between aeolian and fluvial systems in dryland environments. Area, 34(1), 8-16.

Bullard, J.E., McTainsh, G.H., 2003. Aeolian-fluvial interactions in dryland environments: examples, concepts and Australia case study. Progress in Physical Geography, 27(4), 471-501.

Charlton, R., 2008. Fundamentals of Fluvial Geomorphology. Routledge, London and New York.

Draut, A.E., 2012. Effects of river regulation on aeolian landscapes, Colorado River, southwestern USA. Journal of Geophysical Research: Earth Surface, 117(F2), F02022.

Field, J.P., Breshears, D.D., Whicker, J.J., 2009. Toward a more holistic perspective of soil erosion: Why aeolian research needs to explicitly consider fluvial processes and interactions. Aeolian Research, 1(1-2), 9-17.

Fryberger, S.G., 1979. dune forms and wind regimes. In: E.D. McKee (Ed.), A Study of Global Sand Seas. U.S. Government Printing Office.

Good, T.R., Bryant, I.D., 1985. Fluvio-Aeolian Sedimentation: An Example from Banks Island, N. W. T., Canada. Geografiska Annaler. Series A, Physical Geography, 67(1/2), 33-46.

Goudie, A.S., 2013. Arid and semi-arid geomorphology. Cambridge University Press, New York.

Han, G., Zhang, G., Dong, Y., 2007. A model for the active origin and development of source-bordering dunefields on a semiarid fluvial plain: A case study from the Xiliaohe Plain, Northeast China. Geomorphology, 86(3-4), 512-524.

Hollands, C.B., Nanson, G.C., Jones, B.G., Bristow, C.S., Price, D.M., Pietsch, T.J., 2006. Aeolian-fluvial interaction: evidence for Late Quaternary channel change and wind-rift linear dune formation in the northwestern Simpson Desert, Australia. Quaternary Science Reviews, 25(1-2), 142-162.

Huisink, M., 2000. Changing river styles in response to Weichselian climate changes in the Vecht valley, eastern Netherlands. Sedimentary Geology, 133(1-2), 115-134.

Hunter, R.E., Richmond, B.M., Rho Alpha, T., 1983. Storm-controlled oblique dunes of the Oregon coast. Geological Society of America Bulletin, 94(12), 1450-1465.

Jones, L.S., Blakey, R.C., 1997. Eolian-fluvial interaction in the Page Sandstone (Middle Jurassic) in south-central Utah, USA - a case study of erg-margin processes. Sedimentary Geology, 109(12), 181-198. 
Kirkby, M.J., 1978. The stream head as a significant geomorphic threshold. School of Geography, University of Leeds, Leeds.

Krapf, C.B.E., Stollhofen, H., Stanistreet, I.G., 2003. Contrasting styles of ephemeral river systems and their interaction with dunes of the Skeleton Coast erg (Namibia). Quaternary International, 104(1), 41-52.

Langford, R.P., 1989. Fluvial-aeolian interactions: Part I, modern systems. Sedimentology, 36(6), 10231035.

Langford, R.P., Chan, M.A., 1989. Fluvial-aeolian interactions: Part II, ancient systems. Sedimentology, 36(6), 1037-1051.

Leopold, L.B., Wolman, M.G., 1957. River channel patterns: braided, meandering and straight. Geological Survey professional paper;no. 282-B. U.S. Dept. of the Interior, Washington.

Li, S., Dong, G., Shen, J., Yang, P., Liu, X., Wang, Y., Jin, H., Wang, Q., 1999. Formation mechanism and development pattern of aeolian sand landform in Yarlung Zangbo River valley. Science in China Series D: Earth Sciences, 42(3), 272-284.

Liu, L.Y., Skidmore, E., Hasi, E., Wagner, L., Tatarko, J., 2005. Dune sand transport as influenced by wind directions, speed and frequencies in the Ordos Plateau, China. Geomorphology, 67(3-4), 283-297.

Loope, D.B., Swinehart, J.B., Mason, J.P., 1995. Dune-dammed paleovalleys of the Nebraska Sand Hills: Intrinsic versus climatic controls on the accumulation of lake and marsh sediments. Geological Society of America Bulletin, 107(4), 396-406.

Maroulis, J.C., Nanson, G.C., Price, D.M., Pietsch, T., 2007. Aeolian-fluvial interaction and climate change: source-bordering dune development over the past $\sim 100 \mathrm{ka}$ on Cooper Creek, central Australia. Quaternary Science Reviews, 26(3-4), 386-404.

Mazzullo, J.M., Ehrlich, R., 1983. Grain-shape variation in the St. Peter sandstone: a record of eolian and fluvial sedimentation of an early Paleozoic cratonic sheet sand. Journal of Sedimentary Research, 53(1).

Muhs, D.R., Reynolds, R.L., Been, J., Skipp, G., 2003. Eolian sand transport pathways in the southwestern United States: importance of the Colorado River and local sources. Quaternary International, 104(1), 3-18.

Muhs, D.R., Swinehart, J.B., Loope, D.B., Been, J., Mahan, S.A., Bush, C.A., 2000. Geochemical Evidence for an Eolian Sand Dam across the North and South Platte Rivers in Nebraska. Quaternary Research, 53(2), 214-222.

Peterov II, M., 1959. The mineral components and genesis of the aeolian sand on the Ordos, in eastern Alaxan and the middle reaches of the Yellow River. Acta Geographica Sinica, 251-20. (in Russian). 
Ramsey, M.S., Christensen, P.R., Lancaster, N., Howard, D.A., 1999. Identification of sand sources and transport pathways at the Kelso Dunes, California, using thermal infrared remote sensing. Geological Society of America Bulletin, 111(5), 646-662.

Rendell, H.M., Clarke, M.I.L., Warren, A., Chappell, A., 2003. The timing of climbing dune formation in southwestern Niger: fluvio-aeolian interactions and the role of sand supply. Quaternary Science Reviews, 22(10-13), 1059-1065.

Roskin, J., Porat, N., Tsoar, H., Blumberg, D.G., Zander, A.M., 2011. Age, origin and climatic controls on vegetated linear dunes in the northwestern Negev Desert (Israel). Quaternary Science Reviews, 30(13-14), 1649-1674.

Schumm, S.A., 1985. Patterns of Alluvial Rivers. Annual Review of Earth and Planetary Sciences, 13(1), $5-27$.

Smith, N.D., Smith, D.G., 1984. William River: An outstanding example of channel widening and braiding caused by bed-load addition. Geology, 12(2), 78-82.

Song, Y., Yan, P., Liu, L., 2006. A review of the research on complex erosion by wind and water. Journal of Geographical Sciences, 16(2), 231-241.

Sweet, M.L., Nielson, J., Havholm, K., Farrelley, J., 1988. Algodones Dune Field of Southeastern California - Case-History of a Migrating Modern Dune Field. Sedimentology, 35(6), 939-952.

Tastet, J.-P., Pontee, N.I., 1998. Morpho-chronology of coastal dunes in Médoc. A new interpretation of Holocene dunes in Southwestern France. Geomorphology, 25(1-2), 93-109.

Thomas, D.S.G., Stokes, S., Shaw, P.A., 1997. Holocene aeolian activity in the southwestern Kalahari Desert, southern Africa: significance and relationships to late-Pleistocene dune-building events. The Holocene, 7(3), 273-281.

Veiga, G.D., Spalletti, L.A., Flint, S., 2002. Aeolian/fluvial interactions and high-resolution sequence stratigraphy of a non-marine lowstand wedge: the Avilé Member of the Agrio Formation (Lower Cretaceous), central Neuquén Basin, Argentina. Sedimentology, 49(5), 1001-1019.

Ward, J., 1987. The Cenozoic succession in the Kuiseb valley, central Namib Desert. Geological Survey, Department of Economic Affairs (Windhoek, South West Africa/Namibia).

Warren, A., 2013. A History of Dune Sand, Dunes. John Wiley \& Sons, pp. 134-146.

Williams, M.A.J., 2009. Late Pleistocene and Holocene environments in the Nile basin. Global and Planetary Change, 69(1-2), 1-15.

Wilson, I.G., 1972. Aeolian bedforms - their development and origins. Sedimentology, 19(3-4), 173210.

Wu, Z., 1987. Aeolian Geomorphology. Science Press, Beijing. (in Chinese). 
Xu, J., Yang, J., Yan, Y., 2006. Erosion and sediment yields as influenced by coupled eolian and fluvial processes: The Yellow River, China. Geomorphology, 73(1-2), 1-15.

Zhu, Z.D., Wu, Z., Liu, S., Di, X.M., 1980. Introduction to the Sand Deserts in China. Science Press, Beijing. (in Chinese). 